УДК 159.923.2:378.015.31:133.2

DOI https://doi.org/10.26661/2310-4368/2021-4-2

\title{
АКСІОЛОГІЧНИЙ ПІДХІД ДО ФОРМУВАННЯ ДУХОВНОЇ КУЛЬТУРИ МАЙБУТНЬОГО ВЧИТЕЛЯ
}

\author{
Білозерська С. I. \\ кандидат психологічних наук, дочент, \\ доиент кафедри психології \\ Дрогобииький державний педагогічний університет імені Івана Франка \\ вул. Івана Франка, 24, Дрогобич, Львівська область, Україна \\ orcid.org/000-001-9636-1756 \\ Lana_sun@meta.ua
} Ключові слова: аксіологічний
підхід, духовна культура,
педагогічна діяльність,
ичінності, ичіннісні орієнтації.
Стаття присвячена проблемі формування духовної культури майбутнього вчителя, яка значною мірою визначається рівнем педагогічної підготовки, прагненням до самовдосконалення в умовах професійної діяльності. Основоположним $\epsilon$ твердження, що саме аксіологічний підхід до професійної педагогічної підготовки передбачає формування у студентів системи ціннісних орієнтацій, які визначають загальну спрямованість інтересів і прагнень особистості студента, а також розуміння цінностей духовної культури, що забезпечують цілісність та духовну зрілість особистості, прагнення до духовного саморозвитку, самоосвіти. Від характеру діяльності педагога, від його особистісних характеристик, ціннісних орієнтацій, життєвих установок та умов, які він створює, залежить не тільки якість засвоєння школярами встановлених освітнім стандартом знань, а й характер відносин суб'єктів освітнього процесу, атмосфера, в якій відбувається педагогічна взаємодія.

Духовна культура майбутнього вчителя розуміється нами як складна, інтегративна якість, що виражається у високому рівні мотиваційноціннісного та морально-духовного ставлення до педагогічної діяльності, професійно-етичної вихованості, засвоєння морального досвіду та різних сторін духовного життя суспільства, у втіленні засвоєного в поведінці та професійній діяльності. Духовна культура педагога $є$ показником особистісно-професійної зрілості та цілісності особистості; основою для створення власного ціннісного простору, який забезпечить освоєння базових цінностей життя та професійної діяльності.

Здійснюючи змістовну інтерпретацію духовної культури, ми акцентували увагу на таких іiі складниках, як духовні знання, духовні цінності та духовне самовдосконалення. Духовні знання та цінності забезпечують формування у майбутніх педагогів здатності до самостійності, автентичної ціннісної орієнтації, заснованої на світоглядних рефлексіях, переживаннях, оцінках. Основними засобами духовного самовдосконалення є віра, любов, творення добра і боротьба зі злом, творення свободи і відповідальності, праця. 


\title{
AXIOLOGICAL APPROACH TO THE FORMATION OF THE FUTURE TEACHER'S SPIRITUAL CULTURE
}

\author{
Bilozerska S. I. \\ Candidate of Psychological Sciences, Associate Professor, \\ Associate Professor at the Department of Psychology \\ Drohobych Ivan Franko State Pedagogical University \\ Ivan Franko str., 24, Drohobych, Lviv region, Ukraine \\ orcid.org/000-001-9636-1756 \\ Lana_sun@meta.ua
}

Key words: axiological approach, spiritual culture, pedagogical activity, values, value orientations.

\begin{abstract}
The article deals with the problem of forming the spiritual culture of the future teacher, which is largely determined by the level of pedagogical training, the desire for self-improvement in terms of professional activity. Fundamental is the statement that the axiological approach to professional pedagogical training involves formation of students' value orientations, which set the general direction of the interests and aspirations of the student's personality, as well as understanding the values of spiritual culture, ensuring the integrity and spiritual maturity of an individual, striving for spiritual self-development and selfeducation. The nature of the teacher's activity, their personal characteristics, values, life attitudes and conditions that they create define not only the level of knowledge learned by students according to educational standard, but also the nature of the relationship among the subjects of the educational process and the atmosphere in which pedagogical interaction takes place.

The spiritual culture of the future teacher is understood as a complex, integrative quality, which is expressed by a high level of motivational and moral attitude to teaching, professional and ethical level, learning moral experience and various aspects of spiritual life, in the implementation of the acquired knowledge in everyday life and professional activity. The spiritual culture of the teacher is an indicator of personal and professional maturity and integrity of an individual; the basis for creating one's own value environment, which will ensure the development of basic values of life and professional activity.

Meaningfully interpreting the notion of spiritual culture, we focused on such components as spiritual knowledge, spiritual values and spiritual selfimprovement. Spiritual knowledge and values provide the formation of future teachers' ability to independence, authentic value orientation, based on worldview reflections, experiences, assessments. The main means of spiritual self-improvement are faith, love, doing good and fighting the evil, creating freedom and responsibility, and work.
\end{abstract}

Постановка проблеми. В умовах гуманізації та демократизації української освіти зростає необхідність аксіологічної спрямованості підготовки майбутнього вчителя. Сучасні дослідники, аналізуючи аксіогенез професійно-педагогічної підготовки майбутніх педагогів, надають обгрунтування нової методології психології, яка дозволяє виокремити як систему цінностей освітнього процесу, так і освоєння ідеї духовності особистості.

Аналізуючи процес духовного становлення особистості, українські вчені (М. Боришевський, Н. Жигайло, Т. Калюжна, С. Клепко, С. Максименко, М. Савчин, I. Ткачова та інші) вважа- ють, що умовою успішного розвитку духовності $\epsilon$ рання генеза особистості, духовна позиція, власне, вихователів і вчителів, визначеність їхніх ідеалів, розвиток духовних цінностей, релігійної свідомості та самосвідомості особистості. Духовність науковці розглядають як складний психічний феномен самоусвідомлення особистості, внутрішнього сприйняття, привласнення та одухотворення сфери культури, вростання в неї і розуміння як власного надбання $[5-7 ; 11 ; 12 ; 15]$.

Розглядаючи особливості особистісно-професійного розвитку та аналізуючи роль наставництва у духовному зростанні, вчені також акцен- 
тують увагу на побудові індивідуальних освітніх траєкторій для розкриття особистісного та професійного розвитку майбутніх учителів [16].

Такий науковий підхід дозволяє стверджувати, що для особистісно-професійного розвитку майбутнього педагога важливою $є$ не тільки професійна компетентність, але й його духовний світ, духовні якості. Розвиваючись духовно, педагог цінує всю сферу своїх відносин з реальністю, одухотворяє їх, сприймає будь-який об'єкт дійсності як частину свого внутрішнього світу, оцінює дійсність крізь призму духовних цінностей, розвиває «ціннісну увагу» до світу.

Духовність спрямовує особистість до саморозвитку та забезпечує іï цілісність й особистісну зрілість, що $є$ основою формування духовної культури. У цьому контексті необхідно акцентувати увагу на формуванні духовної культури майбутнього вчителя в освітньому процесі. Саме духовна культура вчителя постає, з одного боку, духовною матрицею реального образу педагога (сукупністю духовних здібностей та якостей особистості), а з іншого - внутрішньою культурою, що забезпечує цілісність особистості та саморозвиток, будучи ніби культурою в загальній культурі вчителя, зокрема і в професійній.

Таким чином, сьогодні важливим для української педагогічної освіти є дослідження особливостей розвитку та формування духовної культури майбутнього вчителя, яка детермінована новою парадигмою сталого розвитку суспільства й акцентуацією на екзистенційному людському бутті (духовній свободі, духовній відповідальності) та осмисленні нового трактування духовного ідеалу в умовах інформаційного суспільства.

Мета статті - здійснити змістовну інтерпретацію духовної культури на основі аксіологічного підходу.

Виклад основного матеріалу. Вивчення багатьма дослідниками (M. Боришевським, Н. Жигайло, Т. Калюжною, М. Савчиним, В. Сластьоніним, Н. Ткачовою) $[5 ; 6 ; 11 ; 12 ; 14]$ теоретико-методологічних принципів аксіологічної проблематики в освіті дозволяє розглядати ï як фундамент духовної культури майбутнього педагога. Аксіологічний підхід органічно поєднаний 3 гуманістичною та духовною парадигмами у психології, оскільки людина розглядається в них як найвища цінність суспільства і самоціль загального розвитку. Як підкреслює Ю. Артюхович, «аксіологічний підхід - це філософсько-педагогічна стратегія, яка показує шляхи розвитку професійного мистецтва, використання педагогічних ресурсів для розвитку особистості та пропонує перспективи вдосконалення системи освіти» $[1$, c. 10]. Вчений зазначає, що послідовне і грамотне втілення цього підходу в освітню систему $\epsilon$ показником подальшого духовного розвитку сучасної освіти.

Вочевидь, саме цим можна пояснити розвивальний, облагороджувальний вплив на розвиток особистості майбутнього педагога як потенційно духовної істоти аксіологічних основ, засвоєння яких веде до формування особистісних здатностей (здатності творити добро, вірити, любити, бути відповідальним) та духовних потреб, що передбачають оволодіння вмінням слухати й сприймати іншого, не вносячи у це сприймання спотворень. Зазначені характеристики відображають сутність духовної свідомості й самосвідомості особистості, що лежить в основі людського буття. Саме розвиток аксіосфери майбутнього вчителя «є ключем до істинної творчості, умовою руху до повноти життя, умовою внутрішньої активності, тобто самоактивності, духовної та моральної стійкості особистості» $[4$, с. 78$]$.

Аксіологічний підхід дозволяє розглядати духовність особистості як вищу якість життя, а сенс життя бачить в натхненності, яка втілює ціннісне, морально-духовне ставлення людини до світу, знань, самої себе. Психологічними характеристиками духовності є цінності, ціннісні орієнтації, моральні якості та мотиви поведінки, які сприяють розвитку професійної спрямованості майбутнього вчителя, структуруванню його поведінки відповідно до педагогічної діяльності.

Цінності є стимулом для соціальної і професійної активності вчителя, мають гуманістичну природу та сутність, оскільки зосереджують в собі широкий спектр всіх духовних цінностей суспільства. На їх основі формується ціннісна свідомість педагога, яка $\epsilon$ не тільки результатом його емоційного відгуку на явища життя і професійну діяльність, але й їх осмисленням, глибоким усвідомленням та особистіснім прийняттям. Саме вона, на думку Т. Калюжної, забезпечує становлення гуманістично орієнтованого педагогічного світогляду, системи професійно-ціннісних орієнтацій на емпатійне спілкування з учнями, їх розвиток та особистісне становлення, творчість у праці, реалізацію високого соціального призначення своєї професії та усвідомлення духовного ідеалу [6].

Спрямованість особистості майбутнього педагога на освітні цінності забезпечує формування ціннісних орієнтацій. Будучи не лише елементом духовної сфери, проявом соціальної творчості, ціннісні орієнтації одночасно виступають проєкцією відносин студента до навколишньої соціальної дійсності. В цьому сенсі вони є не лише барометром настроїв студентства, але й індикатором стабільності суспільства. Особливо слід зауважити, що в педагогічній діяльності цінності зосереджені на самій людині, iї внутрішньому світі, моральній моделі поведінки та взаємин. 
Якщо говорити про професійне становлення суб' єкта, то воно передбачає, перш за все, розвиток особистості майбутнього педагога в процесі вибору професії, професійної освіти, підготовки і готовності до виконання професійної діяльності. Важливо, щоб майбутній вчитель ставився до професійної діяльності не тільки як до засобу матеріальної підтримки, а й усвідомлював і відчував благородний вплив трудового процесу на свій розумовий розвиток, на удосконалення психічних функцій і здібностей. Діяльність (в нашому випадку педагогічна), яка сприймається студентом насамперед в особистому, гуманістичному сенсі, є невичерпним джерелом духовного збагачення і зростання особистості.

Слід підкреслити, що діяльність, мотиви якої не пов'язані з усвідомленням іiі соціальної, громадянської значущості, iї духовним сенсом, може спонукати розум і волю майбутнього вчителя до холодного розрахунку, спровокувати в нього мерзенні наміри і дії. Праця, що сприймається людиною тільки як засіб отримання матеріальних благ, засіб збагачення, накопичення, зумовлює появу таких негативних рис, як егоїзм, вигода, вимагання, жадібність, спроби домогтися успіху на роботі будь-якою ціною. Праця, яка не одухотворена в моральному, гуманістичному сенсі, може стати соціально небезпечною, завдати шкоди самій людині, іншим людям, суспільству загалом, що в педагогічній діяльності $є$ недопустимим. Гармонізація почуттів, прагнення до самовдосконалення, самоосвіти, бажання жити у вимірах душі, адекватне ставлення до задоволення матеріальних благ (грошей, кар'єри, слави та інших незначних побутових цінностей, які можуть бути ненаситним джерелом заздрості та інших негативних проявів, руйнування, що зрештою робить людину нещасливою) - все це дозволяє майбутньому вчителю розвинути здатність не тільки бачити, відчувати велич іншої людини як носія духовності, а й активно розвивати це почуття в своєму повсякденному житті й у відносинах з іншими людьми.

Надзвичайно важлива роль у виникненні, становленні та розвитку духовності особистості належить вірі людини. Ідея про позитивний вплив віри в найвищу ідею, в Бога на формування індивідуальної духовності, на прояви духовності у повсякденному житті досить поширена серед багатьох сучасних вітчизняних і зарубіжних психологів $[3 ; 5 ; 7 ; 11 ; 12]$. На їх думку, першою духовною вірою є віра в трансцендентну сутність, або Вищу Силу (Бога). Вчені зазначають, що послідовне й неухильне застосування провідних духовних принципів до буденних ситуацій $є$ ознакою наявності в людини стійких переконань в необхідності розвитку духовності $[11 ; 12]$. Серед них особлива роль належить тим моральним чеснотам, що покладені в основу віри, які є внутрішніми інстанціями, регуляторами духовного життя та поведінки людини.

Вipa виступає також основою виникнення потреби у самоаналізі, що $є$ важливою базою розвитку здатності до педагогічної рефлексії. Формування такої здатності спонукає майбутнього педагога до постійного самовдосконалення, подолання в собі негативних якостей, бажання досягати у своєму духовному розвитку вершин досконалості.

Отже, на значущих ідеях екзистенції людини і суспільства формується так званий загальний «духовний настрій» соціуму як орієнтир дій на фоні інтелектуальної, моральної, емоційної атмосфери. Саме він забезпечує у студентів здатність формувати досконалий інваріант соціальної реальності, що своєю чергою дає можливість відображати морально-духовні стани, моделюючи їх через гармонізацію саморозкриття і самовизначення особистості, духовно-ціннісний порив творити добро, переживання любові, творче натхнення.

Bсе це висуває на перший план проблему повернення освіти і виховання в контекст культури: формування людини культури - вільної, гуманної, духовної, практично-творчої особистості. Саме духовна культура $є$ результатом професійного навчання та виховання і проявляється в необхідності формування системи гуманістичних, соціальних, морально-духовних, особистісних ціннісних орієнтацій особистості, без якої неможливий розвиток суспільства, а також особистісний та професійний розвиток особистості майбутнього вчителя. У випускника повинна скластися завершена стійка система духовно-ціннісних орієнтацій, яка в подальшому іманентно визначатиме його життєвий і професійний шлях.

Спектр теоретичних розробок про розвиток духовної культури вчителя в системі освіти представлений Т. Івановою, І. Ісаєвим, Н. Криловою, Н. Кузьміною, В. Сластьоніним $[2 ; 4 ; 8 ; 9 ; 14]$. Згідно з позицією дослідників духовність культури характеризується втіленням творчих сил істоти духовної - людини. Н. Крилова культуру майбутнього спеціаліста розглядає як вияв зрілості і розвиненості всієї системи соціально значущих особистісних якостей, продуктивно реалізованої в індивідуальній діяльності [8].

Духовна культура педагога виступає показником особистісно-професійноїзрілості та цілісності особистості. Такими особистісними структурами $€$ : високий рівень самосвідомості; інтелектуальна здатність педагога до створення об' єктивної картини світу; усвідомлення педагогом ціннісного наповнення свого «Я» 3 позиції альтруїстичних прагнень; сформованість загальної культури та усвідомлення своєї причетності до світу культури 
українського народу; прояв моральної чистоти в реалізації відповідальності за власні дії та дії інших, готовність і здатність до багатосторонньої співтворчості; сформованість потреб і вмінь творчої діяльності; пізнавальна активність як провідний вид творчої активності; готовність до подальшої самоосвіти, саморозвитку та самовиховання.

Водночас духовна культура $є$ складником, як уже було зазначено, ціннісної свідомості особистості, що визначає характер моральних відносин, а також формування потреби в духовному розвитку. У ній проявляється особистісно-діяльнісна сутність суб' єкта, що відображає трикомпонентну структуру ціннісного ставлення: духовні знання, духовні цінності, духовне самовдосконалення.

Духовні знання дозволяють зберегти традиційні гуманістичні цінності вітчизняної психолого-педагогічної теорії та практики й ефективно використовувати їх у модернізації сучасної української педагогічної освіти. Духовні знання вчителя включають ідеї, закономірності і принципи, привласнення яких дозволяє визначити ставлення педагога до навколишньої дійсності, педагогічної взаємодії, учня, колективу та інших людей.

Духовні знання забезпечують створення власного когнітивного простору - простору знань, вибору і присвоєння цінностей культури й освіти на основі аксіологічно-акцентованих ідей і цінностей освіти, самоактуалізації, самоосвіти і саморозвитку особистості. Це простір, де відбувається переоцінка цінностей, усвідомлення особистісного ставлення до свого місця і ролі в світі, формування образу «Я-духовного», згідно з яким особистість прогнозує, проєктує своє майбутнє.

Оволодіваючи духовними знаннями, майбутній педагог вчиться зіставляти й усвідомлювати мотиви вчинків та поведінки, приймати оптимальні рішення, відстоювати свої позиції і погляди, включається в ситуації морального вибору, має стійкі переконання, володіє внутрішньою свободою та здатний нести відповідальність за свої дії. При цьому він прагне ставити реалістичні цілі, досягати їх навіть у скрутних ситуаціях та особливих умовах, здатний у кризових ситуаціях, якщо це необхідно, переглянути свої мотиви, цілі, побудувати нові цінності та смисли.

Духовні знання є основою формування духовних цінностей, які $є$ важливим складником структури свідомості та самосвідомості особистості і визначають зміст, сутність самосприйняття особистості. Духовні цінності характеризують духовно-моральну сутність суб'єктів, є властивістю буття людини, проявляються в духовно-моральній діяльності і реалізуються як у внутрішньому (духовно-душевному), так і в зовнішньому (духовно-матеріальному) світі людини через свідомість, почуття, поведінку, спілкування, відносини, потреби.
Будучи неповторним, індивідуальним суб'єктом духовності, майбутній педагог досить часто усвідомлює власне «Я» окремо від «не-Я», що здійснює руйнівний вплив на формування духовних цінностей. Деструктивність такого самоусвідомлення полягає в тому, що особистість прагне протиставляти себе іншим, переконана у своїй винятковості, «вищості» порівняно 3 іншими. «Така людина схильна дати свободу для вираження та реалізації будь-яких особистих i, що найгірше, егоїстичних потреб на шкоду інтересам інших людей, які несумісні 3 духовністю» [7, с. 96], тому що егоїстичні орієнтації є непереборною перешкодою на шляху до добра та справедливості.

У контексті викладених вище міркувань варто підкреслити, що зміст аксіологічного підходу як одного 3 найважливіших принципів педагогічного процесу полягає не лише в тому, щоб допомогти студенту усвідомити себе унікальною особистістю, але і в тому, щоб сприяти формуванню в нього здатності бачити себе, своє «Я» як частину «Я-інших людей», тобто «не-Я».

Таким чином, можна стверджувати, що духовні цінності регулюють свідому діяльність та поведінку, надають їм моральний характер, формують ідеал духовного життя майбутнього вчителя, в якому виражається потреба пізнання світу, свого призначення в ньому, сенсу людського буття.

Формування духовної культури пов'язане 3 духовним самовдосконаленням особистості - процесом, який нерозривно поєднаний 3 розвитком та саморозвитком. Це складна, напружена діяльність, спрямована на позитивну зміну себе, своїх думок, почуттів, вчинків, на розвиток своїх можливостей, здібностей, на позитивні зміни навколишнього середовища, на подолання буденності, на оволодіння вищим сенсом життя людського. Як зазначають вчені [13; 15], початок і продовження цієї складної внутрішньої роботи значною мірою залежить від таланту наставника, його людяності, мудрості, його відповідальності за долю вихованця.

Духовно досконалій особистості властива внутрішня свобода, що не суперечить свободі інших. Завдяки цьому людина відрізняється щирістю, рішучістю і гуманістичною спрямованістю своїх життєвих поглядів, орієнтацій, переконань, які вона готова, не афішуючи, наполегливо і відкрито відстоювати, а водночас координувати, уточнювати, покращувати. Духовне самовдосконалення це здатність бачити незвичайне в повсякденному житті, що визначає піднесеність, оптимістичний настрій життя духовно досконалої людини.

Отже, саме аксіологічний підхід забезпечує залучення майбутнього вчителя до методологічних, теоретичних та прикладних знань про 


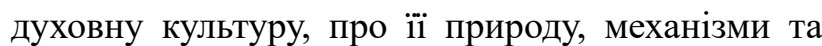
шляхи розвитку, а також про професійно-педагогічні й особистісні цінності, що характеризують професійне становлення та самовдосконалення особистості сучасного вчителя. Застосування цього підходу полягає у формуванні в майбутнього вчителя системи духовних, професійних та загальнолюдських цінностей як визначальних факторів ставлення особистості до світу, обраної професії та себе, розкриття відповідних ціннісних орієнтацій, способів поведінки та життя у світі, наповненому ціннісним змістом.

Висновки і перспективи подальших розробок. Аксіологічна тенденція, яка формується сьогодні в системі української освіти, визнає пріоритетними загальнолюдські цінності, що своєю чергою передбачають розвиток духовної культури майбутнього вчителя як основи для створення власного ціннісного простору, який забезпечить освоєння базових цінностей життя та професійної діяльності. Духовна культура майбутнього вчителя як інтегральна якість особистості включає в себе духовні знання, духовні цінності та духовне самовдосконалення. Формування духовної куль- тури на етапі професіоналізації забезпечить засвоєння студентами морального досвіду та різних сторін духовного життя суспільства, а також втілення засвоєного в поведінку та професійну педагогічну діяльність. Вчитель, що володіє духовною культурою, здатен створити духовну атмосферу для вихованців.

Таким чином, можна стверджувати, що духовна культура передбачає освоєння майбутнім педагогом певних норм і правил, що $є$ найважливішим фактором моральних і життєвих регуляторів під час прийняття та вибору як життєвих, так і професійних рішень та цілей. Це широкий простір вибору життєвих орієнтирів, розвитку прогностичних здібностей, визначення ідеалів і моделей майбутнього життя та діяльності, в якому особистість усвідомлює цілі і смисли майбутнього життя, вибудовує та реалізує їх проєкт.

Враховуючи специфіку педагогічної діяльності та важливість оволодіння духовною культурою для майбутнього вчителя, подальших наукових розвідок потребує висвітлення проблеми iii показників та створення динамічної моделі іiі формування.

\section{ЛІТЕРАТУРА}

1. Артюхович Ю. Моральная дискретность личности в информационном социуме. Вестник Омского государственного педагогического университета. Гуманитарные исследования. 2015. № 3. C. $10-13$.

2. Іванова Т. Професійна культура майбутнього вчителя. Педагогіка і психологія. 1995. № 2. С. 86-93.

3. Исаев И. Профессионально-педагогическая культура преподавателя : учебное пособие. Москва : Академия, 2002. 208 с.

4. Исаев И. Теория и практика формирования профессиональной педагогической культуры преподавателей высшей школы. Москва : Белгород, 1993. 219 с.

5. Жигайло Н. Психологія духовного становлення особистості майбутнього фахівця : монографія. Львів : Видавничий центр ЛНУ ім. Івана Франка, 2008. 336 с.

6. Калюжна Т. Педагогічна аксіологія в умовах модернізації професійно-педагогічної освіти : монографія. Київ : Видавництво НПУ ім. М.П. Драгоманова, 2012. 128 с.

7. Клепко С. Цінності буття і цінності освіти в контексті глобалізації. Харків : Основа, 2004. 128 с.

8. Крылова Н. Формирование культуры будущего специалиста. Москва : Высшая школа, 1990. 140 с.

9. Кузьмина Н. Акмеологическая концепция развития профессиональной компетентности в вузе : монография. Санкт-Петербург : Издательство НУ «Центр стратегических исследований», 2012.200 с.

10. Митина Л. Психология профессионального развития учителя. Москва : Флинта, 1998. 236 с.

11. Психологічні закономірності розвитку духовності особистості : монографія / за ред. М. Боришевського. Київ : Педагогічна думка, 2011. 200 с.

12. Савчин М. Духовний потенціал людини : монографія. Івано-Франківськ : Місто НВ, 2010. 508 с.

13. Сластенин В. Введение в педагогическую аксиологию : учебное пособие / В. Сластенин, Г. Чижакова. Москва : Академия, 2003. 192 с.

14. Сластенин В. Аксиологические основы педагогики. Москва : Школа-Пресс, 1998. 512 с.

15. Ткачова I. Аксіологічний підхід до організації педагогічного процесу в загальноосвітньому навчальному закладі : монографія. Луганськ : ЛНПУ ім. Тараса Шевченка ; Харків : Каравела, 2006. $300 \mathrm{c}$.

16. Construction of an Individual Educational Trajectory as a Way to Reveal the Personal and Professional Potential of a Future Teacher / A. Klieba et al. International Journal of Higher Education. 2020. Vol. 9. № 7 (Special Issue). P. 73-84. DOI: 10.5430/ijhe.v9n7p73. 


\section{REFERENCES}

1. Artyukhovich, Yu. (2015) Moralnaya diskretnost lichnosti v informatsionnom sotsiume [Moral discreteness of personality in the information society]. Bulletin of the Omsk state pedagogical university. Humanitarian research. Issue 3, pp. 10-13.

2. Ivanova, T. (1995) Profesiyna kultura maybutnioho vchytelia [Professional culture of the future teacher]. Pedahohika i psykholohiya. Issue 2, pp. 86-93.

3. Isaev, I. (2002) Professionalno-pedagogicheskaya kultura prepodavatelya [Professional and pedagogical culture of the teacher]: a textbook. Moscow : Academy. 208 p.

4. Isaev, I. (1993) Teoriya i praktika formirovaniya professionalnoy pedagogicheskoy kultury prepodavateley vysshey shkoly. [Theory and practice of formation of professional pedagogical culture of higher school teachers]. M. : Belgorod. 219 p.

5. Zhyhaylo, N. (2008) Psykholohiya dukhovnoho stanovlennia osobystosti maybutnioho fakhivtsia [Psychology of spiritual development of the future professional]: Monograph. Lviv : Ivan Franko Lviv National University Publishing Center. $336 \mathrm{p}$.

6. Kaliuzhna, T. (2012) Pedahohichna aksiolohiya v umovakh modernizatsiyi profesiyno-pedahohichnoyi osvity [Pedagogical axiology in the conditions of modernization of professional and pedagogical education]: monograph. K. : Publishing house of M.P. Dragomanov NPU. 128 p.

7. Klepko, S. (2004) Tsinnosti buttya i tsinnosti osvity v konteksti hlobalizatsiyi [Values of existence and values of education in the context of globalization]. Kharkiv : Osnova. 128 p.

8. Krylova, N. (1990) Formirovanie kultury budushchego spetsialista [Formation of the culture of the future specialist]. Moscow : Vyssha shkola. $140 \mathrm{p}$.

9. Kuzmina, N. (2012) Akmeologicheskaya kontseptsiya razvitiya professionalnoy kompetentnosti v vuze [Acmeological concept of development of professional competence in higher education]: monograph / N. Kuzmina, V. Sofyina. SPb. : NU "Center for Strategic Studies" Publishing. 200 p.

10. Mitina, L. (1998) Psihologiya professyonalnogo razvitiya uchitelya [Psychology of teachers' professional development. M. : Flinta. 236 p.

11. Psykholohichni zakonomirnosti rozvytku dukhovnosti osobystosti [Psychological patterns of development of spirituality of an individual]: a monograph / ed. M. Boryshevsky. Kyiv : Pedahohichna dumka, 2011. 200 p.

12. Savchyn, M. (2010) Dukhovnyy potentsial lyudyny [The spiritual potential of a person]: a monograph. Ivano-Frankivsk : Misto NV. 508 p.

13. Slastenin, V. (2003) Vvedenie v pedagogicheskuyu aksiologiyu [Introduction to pedagogical axiology]: textbook for students of higher pedagogical institutions / V. Slastenin, G. Chizhakova. M. : Akademiya. $192 \mathrm{p}$.

14. Slastenin, V. (1998) Aksiologicheskie osnovy pedagogiki [Axiological foundations of pedagogy]. M. : Shkola-Press. 512 p.

15. Tkachova, I. (2006) Aksiolohichnyy pidkhid do orhanizatsiyi pedahohichnoho protsesu v zahalnoosvitniomu navchalnomu zakladi [Axiological approach to the organization of the pedagogical process in a secondary school]: monograph. Luhansk: Taras Shevchenko LNPU; Kharkiv : Karavela. 300 p.

16. Construction of an Individual Educational Trajectory as a Way to Reveal the Personal and Professional Potential of a Future Teacher / A. Klieba et al. International Journal of Higher Education. 2020. Vol. 9. № 7 (Special Issue). P. 73-84. DOI: 10.5430/ijhe.v9n7p73 